\title{
Perkembangan Penyajian Jathilan di Daerah Istimewa Yogyakarta
}

\author{
Kuswarsantyo ${ }^{1}$, Timbul Haryono, dan R.M Soedarsono \\ Program Pengkajian Seni Pertunjukan dan Seni Rupa, Sekolah Pascasarjana, Universitas Gadjah Mada Yogyakarta
}

\begin{abstract}
The Horse Dance in Yogyakarta. Artikel ini membahas perjalanan sejarah kesenian Jathilan hingga memasuki era Globalisasi. Pasang surut kesenian Jathilan telah dialami dari waktu ke waktu, termasuk juga dalam aspek fungsi penyajian. Kini Jathilan dapat bebas disajikan tanpa terkait dengan upacara seremonial tertentu. Hadirnya industri pariwisata yang dicanangkan pemerintah tahun 1986, merupakan era baru yang disebut dengan Globalisasi. Program pariwisata memberikan dampak luar biasa bagi pengembangan sajian seni Jathilan. Interaksi sosial antar wilayah memberi kontribusi terhadap upaya pengemasan bentuk sajian Jathilan untuk konsumsi wisatawan. Pengaruh tersebut terjadi karena dua faktor, pertama faktor eksternal dan kedua faktor internal. Dua pengaruh ini yang memberi sinyal akan berkembangnya bentuk sajian Jathilan yang tidak lagi hanya dipentaskan untuk acara seremonial tertentu. Penerapan konsep pseudo traditional art, dengan mengutamakan sajian kemasan yang singkat padat, penuh variatif, telah dihilangkan unsur ritual, tiruan bentuk aslinya dan murah harganya.

Kata kunci: jathilan, horse dance, seni tradisional, globalisasi seni.
\end{abstract}

\section{Pendahuluan}

Jathilan adalah salah satu dari sekian banyak genre kesenian tradisional yang ada di wilayah Daerah Istimewa Yogyakarta (DIY). Dalam penampilannya kesenian Jathilan menggunakan properti kuda kepang. Pertunjukan Jathilan ditampilkan dengan mengambil cerita roman Panji (Th. Pigeaud, 1934: 316). Namun dalam perkembangannya, kini Jathilan tidak hanya bertumpu pada cerita roman Panji, karena saat ini banyak grup Jathilan di Daerah Istimewa Yogyakarta mengambil setting cerita Wayang (Mahabarata atau Ramayana) dan dapat pula Legenda Rakyat setempat (Wawancara dengan Sancoko, 2 Maret 2010).

Secara fungsional kesenian Jathilan memiliki peran yang penting dalam kehidupan masyarakat, sebagai bagian dari kegiatan sosial, yang lebih dikenal sebagai sarana upacara, seperti merti desa atau bersih desa. Keberadaan Jathilan dalam acara merti desa memberikan efek sosial bagi masyarakat pendukungnya sebagai sarana gotong royong. Nilai nilai gotong royong dalam kesenian Jathilan ini tercermin dalam upaya untuk saling memberi dan melengkapi kekurangan kebutuhan artistik, misalnya pengadaan instrumen, tempat latihan, hingga pengadaan kostum (Nuryani, 2008: 6)
Kenyataan yang terjadi dalam kehidupan masyarakat komunitas Jathilan adalah, rasa ketergantungan satu individu pada individu lain dalam menjalankan kehidupannya. Hubungan ini terjadi dari waktu ke waktu, menjadi semakin kompleks, baik dari sisi kuantitas maupun macam hubungannya. Dampak dari interaksi antar individu tersebut maka terbentuk sistem nilai, pola pikir, sikap, perilaku kelompok kelompok sosial, kebudayaan, lembaga, dan lapisan atau stratifikasi sosial (Soerjono Soekanto, 2003: 51)

Keberadaan kesenian Jathilan tidak dapat lepas dari konteks kebudayaan yang ada dalam masyarakat. Oleh sebab itu perlu kiranya memahami posisi kesenian dalam konteks kebudayaan yang menurut Koentjaraningrat dapat dikategorikan berdasarkan pada ide gagasan, aktivitas yang kompleks, dan aspek hasil karya dan produk (Koentjaraningrat, 1986: 273)

Mengacu pada pendapat Koentjaraningrat tersebut dapat dikatakan bahwa, hasil penciptaan karya seni tidak dapat terlepas dari komunitas kehidupan masyarakat yang memiliki berbagai aktivitas di samping keinginan melestarikan kesenian tradisional yang mereka miliki. Salah satu kesenian yang hidup berkembang di kalangan masyarakat adalah Jathilan. Kesenian Jathilan

1 Alamat korespondensi: Prodi Pengkajian Seni Pertunjukan dan Seni Rupa UGM, Gedung Lengkung Jalan Teknika Utara, Pugung, Yogyakarta. Telepon: 081328090666.Email: condrowasesa@yahoo.co.id 
banyak tumbuh dan berkembang di pelosok desa yang sering dikaitkan atau dihubungkan dengan kepercayaan animistik. Hal ini dapat dilihat dari pementasan Jathilan, yang pada bagian akhir pertunjukan menghadirkan adegan trance (ndadi). Konsep trance ini sebenarnya merupakan bagian dari sebuah acara ritual, yang dalam pandangan Daniel L. Pals merupakan rangkaian upacara ritual pada klen tertentu (Daniel L. Pals, 1996: 181). Keterkaitan upacara ritual dengan komunitas itu menghasilkan pola pola tradisi yang sudah ada dan hidup di masyarakat dengan ciri kesederhanaan, seperti yang dimiliki kesenian Jathilan.

Kesenian Jathilan mengalami perkembangan yang 'signifikan' seiring dengan bergulirnya era global yang ditandai dengan pencanangan program pariwisata oleh pemerintah. Presiden Soeharto ketika itu menekankan perlunya memprioritaskan sektor non migas untuk devisa negara. Pernyataan ini disampaikan pada pembukaan rapat kerja Departemen Pariwisata Pos dan Telekomunikasi 26 September 1986 (R.M. Soedarsono, 1999: 1). Kesenian tradisional sejak itu menjadi objek untuk mengeruk keuntungan tersebut.

Pengaruh Globalisasi yang ditandai dengan munculnya program pariwisata itu menghadirkan permasalahan estetik yang menyertai kesenian tradisional Jathilan. Pertama, permasalahan estetik yang muncul sangat kompleks, terkait dengan sumber acuan cerita, koreografi, pengembangan iringan, kostum, hingga munculnya beragam jenis Jathilan. Kedua, menghasilkan perbedaan gaya dan karakter atau ciri, serta keunikan tersendiri. Ketiga, dampak dari perkembangan adanya pariwisata itu secara kuantitas memunculkan grup kesenian Jathilan di DIY yang jumlahnya mencapai ratusan buah.

Pengaruh lain disebabkan karena telah terjadinya akulturasi budaya yang menimbulkan benturan antara budaya modern yang kapitalistik dengan budaya tradisional. Budaya tradisional dalam konteks ini adalah kesenian Jathilan, dan budaya kapitalistik adalah budaya yang berorientasi untuk mencari keuntungan, seperti halnya program pariwisata. Pengaruh ini tentu saja akan berdampak pada citarasa kesenian Jathilan yang menjadi bervariasi. Banyak pilihan model atau tipe Jathilan muncul, seiring dengan perkembangan pariwisata. Tipe atau model
Jathilan yang muncul itu membawa konsekuensi di antara masyarakat komunitas Jathilan. Ada sebagian menyatakan sependapat dan sebagian lain tidak sependapat. Kontradiksi dalam penyajian Jathilan ini merupakan permasalahan estetik yang lebih banyak disebabkan karena faktor permintaan pasar (tanggapan).

Umar Kayam mengungkapkan bahwa benturan tersebut terjadi pada aspek perbedaan antara tradisi dan modern, yang dikatakan sebagai berikut.

Modernisasi menuntut hidup yang lugas (zakelijk), rasional, dan memandang jauh ke depan dalam perkembangan. Modernisasi merobek robek kosmos yang bulat integral menjadi kotak pembagian kerja yang disebut spesialisasi dan berbagai keahlian. Sedangkan seni tradisional adalah bentuk seni dalam kenikmatannya. Ia tidak terlalu berkepentingan dengan kecepatan waktu serta kecepatan perombakan. Ia mengabdi kepada harmoni serta keseimbangan abadi dari sang kosmos (Kayam, 1981: 63).

Dalam konteks modernisasi seperti yang dikemukakan Kayam, peran pelaku wisata seperti biro travel dalam mengemas kesenian tradisional termasuk Jathilan untuk konsumsi wisatawan, adalah bukti nyata bahwa kesenian tradisional kini telah menjadi bagian dari komersialisasi budaya yang disebut pariwisata. Hal ini dipertegas dengan pendapat Yoety, yang memberikan definisi industri pariwisata sebagai satu gejala komersialisasi seni budaya, yang dalam pelaksanaannya masih mempertimbangkan usaha pelestarian kesenian tradisional (Yoety, 1983: 11). Kenyataan ini tidak bisa kita hindarkan, karena pengaruh budaya melalui media teknologi informasi maupun dari gaya hidup dan perilaku yang ditayangkan melalui televisi sangat cepat memberi inspisrasi masyarakat. Kondisi demikian dipertegas dengan pendapat Koentjaraningrat dalam sebuah teori evolusi sosial universal yang mengatakan bahwa, manusia akan selalu bergerak menuju ke arah kemajuan, sehingga manusia di dunia ini telah berkembang dari tingkat sederhana ke tingkat yang semakin tinggi serta kompleks (Koentjaraningrat, 1980: 31).

Perkembangan seni Jathilan dari waktu ke waktu itu melebarkan fungsi tidak hanya sebagai bagian upacara namun menjadi tontonan atau 
hiburan masyarakat. Hal ini sejalan dengan pendapat R.M. Soedarsono yang membagi fungsi primer tari menjadi tiga yakni: 1) sebagai sarana ritual keagamaan, 2) sebagai hiburan pribadi, dan 3) sebagai presentasi estetis (Soedarsono, 2002: 125). Dari fungsi pertama sebagai sarana ritual telah dilakukan pada era 1930 an. Kemudian di era pariwisata yang dimulai tahun 1986, Jathilan bergeser fungsinya sebagai sarana hiburan. Dan ketiga, di era 2000 an, seni Jathilan menjadi acuan penggarapan karya tari untuk kepentingan tertentu. Perkembangan fungsi tari secara primer ini membuktikan bahwa seni tradisional dapat hidup dinamis. Dalam konteks ini, dikaji mengenai bagaimana peran masyarakat dikaitkan dengan perkembangan bentuk sajian jatilan saat ini.

\section{Globalisasi Kebudayaan}

Kenyataan tersebut menghasilkan benturan antara nilai tradisional yang mengabdi pada harmoni, keselarasan, dan mistis dengan nilai modern yang cenderung kapitalistik (Purwanto, 2000: 79-81). Fenomena tersebut menarik untuk dikaji kaitannya dengan pengaruh Globalisasi terhadap perkembangan bentuk penyajian kesenian Jathilan yang terjadi di wilayah Daerah Istimewa Yogyakarta. Globalisasi kebudayaan telah mengikuti pola yang sama dengan globalisasi ekonomi. Kebudayaan universal muncul, disebarkan melalui semakin banyaknya media global yang kebanyakan dikendalikan oleh, dan bekerja untuk kepentingan modal transnasional. Televisi, musik, arsitektur, makanan, minuman, pakaian, film, olahraga, dan bentuk-bentuk rekreasi lainnya semakin serupa, di manapun tempatnya di dunia. Kota yang satu sangat mirip dengan kota-kota lainnya, hotel bentuknya sama di seluruh dunia, dan televisi, iklan dan teknologi komputer tampaknya bekerja tak kenal lelah untuk mewujudkan keseragaman.

Dalam menghadapi globalisasi kebudayaan, sangat sulit bagi masyarakat untuk melestarikan kebudayaan lokalnya sendiri yang unik, walaupun ini merupakan komponen penting dari pembangunan masyarakat. Prinsip keanekaragaman (diversity) mengharuskan bahwa keanekaragaman (diversity) kebudayaan dipertahankan; kebudayaanlah yang memberikan kepada warga masyarakat (people) rasa memiliki dan identitas, sehingga pembangunan kebudayaan menjadi penting artinya bagi masyarakat. Di dalam konteks pembangunan masyarakat, pembangunan kebudayaan mempunyai empat komponen: melestarikan dan menghargai kebudayaan lokal, melestarikan dan menghargai kebudayaan asli, multi-kulturalisme dan kebudayaan partisipatoris (participatory culture).

\section{Melestarikan dan Mengembangkan Kebudayaan Lokal}

Dari sekian ratus grup kesenian Jathilan yang tercatat di Dinas Kebudayaan Propinsi DIY, secara umum hampir semua grup telah melakukan inovasi atau penggarapan sajian Jathilan. Ini merupakan indikasi bahwa seniman Jathilan telah menyadari akan perkembangan selera estetis masyarakat penontonnya. Modernisasi di segala bidang kehidupan dalam kehidupan masyarakat nampaknya telah menggerakkan daya kreativitas para seniman untuk mengolah dan menggarap kesenian tradisional agar lebih bisa diterima masyarakat penikmatnya.

Selama ini kesenian rakyat Jathilan secara umum dipahami sebagai kesenian yang memiliki ciri ciri sederhana, baik teknik menari, rias, busana, maupun iringannya. Selain itu Jathilan mudah dipelajari secara turun menurun dengan menirukan pola yang sudah ada (pakem). Pendapat di atas saat ini sudah mulai bergeser seiring dengan perkembangan zaman. Seperti diungkapkan Pigeaud, bahwa seni pertunjukan rakyat di luar daerah Swapraja terasa jauh lebih berkembang dan para senimannya lebih berani dalam melakukan olah kreativitas. Hal ini disinyalir karena kuatnya pengaruh kesenian klasik di kraton yang telah mapan, sehingga memunculkan beban psikologis bagi seniman di daerah swapraja untuk melakukan inovasi.

Geertz mengungkapkan hal ini bahwa kesenian klasik seperti beksan, srimpi, wireng, ringgit tiyang, ringgit kulit, identik dengan kesenian priyayi atau golongan masyarakat yang berstatus sosial tinggi. Sementara kesenian rakyat semacam Reyog, Jathilan, Slawatan, Tayub, dan sejenisnya selalu dianalogkan sebagai jenis kesenian untuk golongan masyarakat kelas bawah, atau wong cilik. 


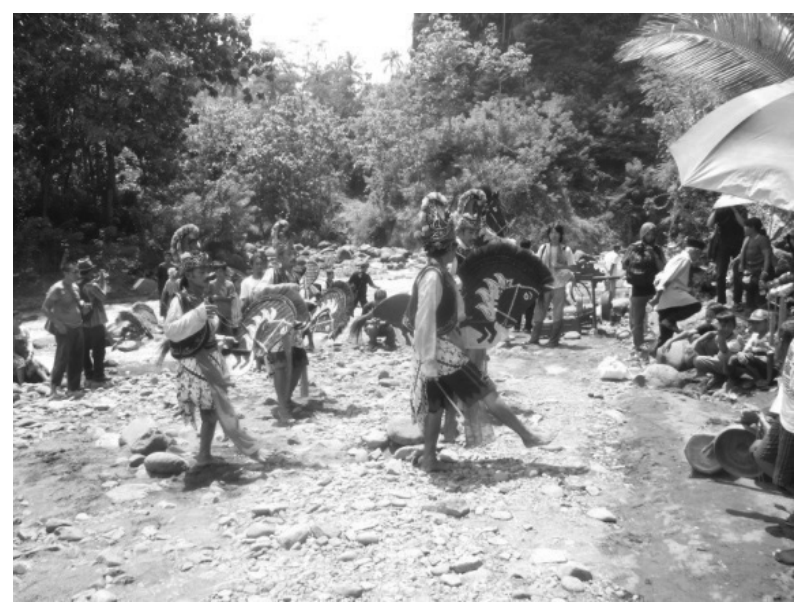

Gambar 1 :

Jathilan sebagai bagian dari acara ritual desa, merupakan representasi masyarakat kelas bawah (Foto: Santyo, 2009)

Dalam kaitannya dengan konteks perkembangan dan pelestarian kesenian tradisional perlu dilakukan dengan cermat dan dengan konsep pemahaman yang matang serta proporsional. Pengembangan harus dilakukan dengan dasar atau rujukan yang tepat, sehingga tidak merusak esensi seni tradisi yang dikembangkan. Oleh sebab itu pengembangan kesenian tradisional Jathilan hendaknya didasarkan pada konsep yang jelas, sehingga akan dapat diwariskan kepada generasi berikut sebagai sebuah kekayaan seni tradisi yang dimilikinya. Keberlangsungan seni tradisi tidak hanya tergantung pada satu sisi, misalnya dari sisi garap tari. Namun harus pula dipikirkan hakekat kesenian tradisi sebagai kesenian komunal yang menjadi identitas budaya masyarakat pendukungnya. $\mathrm{Hal}$ ini seiring dengan perkembangan arus modernisasi yang dianggap sebagai ancaman sekaligus tantangan untuk kelestarian seni tradisional, seperti pernah diungkapkan Kayam tahun 1985, bahwa apakah kesenian tradisional kita mampu mempertahankan sosoknya yang asli dan fungsinya yang lama di tengah masyarakat yang sedang terbawa pada arus modernisasi saat ini (Kayam, 1984: 15)

Pada situasi seperti saat ini di mana arus perubahan budaya seiring dengan program globalisasi memberikan konsekuensi terhadap perkembangan budaya. Sri Sultan Hamengku Buwana X, pernah menyampaikan pendapatnya bahwa kecenderungan individualisasi perlu kita perhatikan, bahwa proses modernisasi itu sendiri berlangsung di tengah masyarakat yang sesungguhnya masih bersifat komunal tradisional (Hamengku Buwana X, 1998: 2).

Pernyataan Sultan Hamengku Buwana X tersebut ternyata terbukti pada sepuluh tahun terakhir ini yang mana muncul beberapa gerakan budaya yang berorientasi pada kekuatan dan kearifan budaya lokal. Berbagai upacara adat yang dulu terhenti, kini mulai dihidupkan kembali dengan adanya program desa budaya atau desa wisata. Dengan maraknya acara adat di desa-desa tersebut maka berdampak pula pada perkembangan kesenian tradisional yang ada. Keberadaan kesenian tradisonal dalam upacara adat tidak dapat dipisahkan, sehingga makin berkembangnya upacara adat tradisi maka akan diikuti pula oleh perkembangan seni tradisional yang ada.

Tradisi kebudayaan lokal merupakan bagian penting dari rasa bermasyarakat, dan membantu memberikan rasa identitas kepada masyarakat. Maka dari itu, pembangunan masyarakat akan selalu berusaha untuk mengidentifikasi elemen-elemen penting dari kebudayaan lokal, dan melestarikannya. Ini dapat termasuk di dalamnya sejarah lokal dan warisan, kerajinan tradisional, makanan dan produk lokal lainnya, dan di dalam beberapa kasus juga bahasa lokal. Masyarakat mungkin mempunyai tradisi-tradisi khusus, seperti festival atau fair (pasar raya), upacara ritual yang berkaitan dengan masyarakat etnis tertentu. Sebagaimana dengan aspek-aspek pembangunan masyarakat lainnya, mungkin tidak ada resep bagaimana cara mencapainya. Inisiatif harus berasal dari masyarakat itu sendiri, dan cara melaksanakannya akan bervariasi dari satu masyarakat dengan masyarakat lainnya, sesuai dengan kondisi-kondisi lokal, kebudayaan, ekonomi, dan sebagainya. Agar pembangunan kebudayaan efektif di dalam konteks pembangunan masyarakat yang lebih luas, kebudayaan tidak boleh dipisahkan dari kehidupan masyarakat, tetapi harus dipandang sebagai suatu bagian nyata dari kehidupan masyarakat. Bila ini tercapai, tradisi kebudayaan lokal dapat menjadi titik fokus untuk interaksi sosial, pelibatan masyarakat dan partisipasi berbasis luas, dan dapat menjadi proses penting di dalam aspek-aspek lain dari pembangunan masyarakat, seperti pembangunan sosial, pembangunan ekonomi, atau pembangunan politik. 
Pengaruh perkembangan zaman tersebut diikuti dengan berbagai aktivitas yang mampu memberikan dampak sosial, ekonomi, kultural seperti yang terjadi dalam dunia kepariwisataan. Setelah itu dari tahun ke tahun program pariwisata berkembang pesat dan puncaknya terjadi ketika harga minyak bumi di pasaran dunia menurun serta terjadinya devaluasi nilai rupiah tanggal 12 September 1986. Sejak itu pariwisata mulai meningkat. Oleh karenanya, presiden Soeharto menekankan peningkatan sektor pariwisata dalam pidato pembukaan pertemuan nasional dengan Menteri Pariwisata Pos dan Telekomukasi Republik Indonesia, 26 September 1986 (Soedarsono, 1989/1990: 1).

\section{Kesenian sebagai Asset Pariwisata}

Laju perkembangan budaya dalam menghadapi tantangan globalisasi memang tidak harus dihadapi dengan sikap apatis. Namun kita harus tetap optimis dalam menghadapi segala situasi dengan memanfaatkan seoptimal mungkin kemampuan yang kita miliki untuk menghadapi tantangan globalisasi tersebut. Hal itu dibuktikan dengan masuknya salah satu unsur kebudayaan yang bernama kesenian menjadi bagian penting dalam program pariwisata.

Semenjak seni pertunjukan menjadi bagian penting dalam program pariwisata, frekuensi penyajian seni pertunjukan untuk konsumsi wisatawan makin marak berkembang di berbagai tempat di wilayah Daerah Istimewa Yogyakarta. Keberadaan seni pertunjukan sebagai asset wisata memberikan kontribusi pada pelestarian budaya yang dimiliki masyarakat. Hal ini ditandai dengan meningkatnya tawaran pementasan oleh grup grup kesenian yang ada di Daerah Istimewa Yogyakarta, baik seni pertunjukan klasik maupun kerakyatan.

Perkembangan kesenian secara umum dapat dikategorikan menjadi dua bagian. Pertama mengembangkan dalam arti upaya untuk menyebarluaskan kesenian agar jangkauan wilayahnya lebih luas. Kedua, pengembangan dalam arti melakukan pembenahan secara teknik atau penggarapan kembali kesenian agar lebih menarik dan dinamis (Sedyawati, 1981: 34) Oleh sebab itu upaya pengembangan yang bersifat sosial atau penyebaran sering kali disertai dengan upaya upaya pengembangan yang bersifat teknik agar mudah diterima dan lebih disenangi oleh masyarakat yang lebih luas. Upaya sosialisasi kesenian tradisional yang tidak maksimal tentu tidak akan mendapat dukungan masyarakat. Sebaliknya sosialisasi kesenian tradisional yang disertai dengan pengolahan baru (inovasi) lebih bisa diterima oleh masyarakat sekarang. Terlebih lagi di era Pariwisata, di mana seni pertunjukan telah menjadi bagian dari komoditi yang dapat diandalkan untuk mendatangkan wisatawan baik domestik maupun mancanegara. Daya tarik dari sektor pariwisata inilah yang memacu perkembangan seni kerakyatan khususnya Jathilan untuk dikembangkan sesuai dengan selera estetis dalam program pariwisata.

Dengan dasar tersebut hendaknya dalam membuat tiruan bentuk aslinya harus benar benar tahu pada akar tradisi yang dikembangkan. Hal ini penting diketahui karena supaya apa yang dikembangkan untuk sajian wisata tetap merujuk pada bentuk aslinya. Dengan demikian nilai nilai keaslian tradisi tetap dapat terjaga seiring dengan pengembangan yang dilakukan untuk kepentingan pariwisata.

Dari aspek sosial, hadirnya industri pariwisata mampu membuka lapangan kerja baru bagi seniman seni pertunjukan dalam ikut menyemarakkan program pariwisata. Kenyataannya, seni pertunjukan pada umumnya berfungsi sosial, maka tak mengherankan apabila kehadiran masyarakat pengunjung (wisatawan) di Indonesia akan melahirkan pula produk produk seni pertunjukan yang bisa kita kategorikan sebagai seni wisata (tourist art), yaitu seni pertunjukan yang dikemas secara khusus untuk melayani selera wisatawan (Soedarsono, 1990: 46)

Masalah ini selanjutnya akan bertitik tolak pada masalah seni dan masyarakat penikmat. Dalam konteks pariwisata, masyarakat penikmat adalah wisatawan, baik mancanegara maupun nusantara. Seni di sini sebagai epi fenomenon atau gejala kedua, di mana akan diungkapkan bagaimana kondisi sosial digambarkan dengan seni.

Sisi lain bagaimana kelembagaan seni (pengelola seni pertunjukan wisata) itu menempatkan diri sebagai bagian dari lembaga masyarakat (wisatawan). Artinya, bagaimana sebuah organisasi kesenian mengemas produk seninya agar menarik disajikan kepada wisatawan. Seni di sini mempunyai peran dan fungsi sebagai lembaga 
sosial, karena kata fungsi selalu menunjukkan pada pengaruh terhadap sesuatu yang lain. Apa yang dinamakan fungsional tidak berdiri sendiri, tetapi justru dalam satu hubungan tertentu memperoleh arti dan maknanya (Kayam, 1981: 15)

Dengan demikian antara seni dan masyarakat harus saling mendukung untuk mencapai makna tertentu dalam sebuah pertunjukan. Ditinjau dari sisi pengembangan budaya, melalui industri pariwisata, seni pertunjukan akan semakin tumbuh dan berkembang. Artinya kehadiran seni wisata tidak akan merusak ekosistem dalam seni pertunjukan, karena penerapan konsep seni wisata yang tepat justru akan memperkaya khasanah seni pertunjukan.

Dari aspek politik, di samping olah raga, kesenian telah terbukti mampu berfungsi sebagai media pemersatu antar bangsa, maka tak heran kalau seni pertunjukan dalam kemasan wisata yang digunakan untuk promosi budaya di Amerika Serika (KIAS tahun 1990) mempunyai tujuan ganda yang secara politis juga sangat bermanfaat bagi pengenalan Indonesia di forum internasional.

Dengan demikian dapat dikatakan bahwa akibat sentuhan industri pariwisata, maka seni pertunjukan kuantitas sajiannya makin nampak kita rasakan. Sebagai bukti, penawaran untuk pertunjukan seni wisata mankin meningkat frekuensi penyajiannya, sehingga tiap hari dapat kita temukan pertunjukan wisata baik yang terjadi di tempat tempat khusus seperti Purawisata, Prambanan, ataupun kawasan objek wisata yang menghadirkan kesenian rakyat sebagai sajiannya.

Berbicara mengenai perkembangan seni pertunjukan untuk wisata, secara umum dapat dibagi dua berdasarkan jenis penikmatnya, 1) Seni yang tujuan pembuatannya sebagai konsumsi untuk masyarakat setempat (art by destination), 2) Produk seni yang dibuat khusus bagi masyarakat lain atau masyarakat luar daerah (art by metamorphosis) seni di sini harus mampu menyesuaikan selera penikmatnya yang berasal dari luar komunitasnya (art of acculturation). Dalam hal ini seni tradisional daerah masih dipertahankan sebagai daya tarik tersendiri, meski sakralitas pertunjukannya sudah dihilangkan. Maka seni akulturasi ini dapat disebut dengan pseudo tradisional art atau seni tiruan (Grabburn, 1976: 71)
Hadirnya industri pariwisata di Daerah Istimewa Yogyakarta memberikan angin segar bagi tumbuh dan berkembangnya seni pertunjukan. Di samping itu, lahirnya seni pertunjukan wisata mampu memacu kreativitas serta mendukung pelestarian budaya. Dengan frekuensi penyajian yang meningkat itu, kini masyarakat seni pertunjukan, khususnya yang aktif mendukung seni wisata ditantang untuk lebih serius dalam menampilkan kemasan pertunjuukan wisata. Serius dalam pengertian ini adalah tidak sekedar asal tampil tanpa memikirkan aspek kualitas. Demikian pula untuk aspek fleksibilitas dalam menghadapi tantangan industri pariwisata, seni pertunjukan harus mampu menyesuaikan dengan keadaan. Maksudnya adalah bentuk pertunjukan yang akan disajikan harus fleksibel dan tidak kaku seperti dipersyaratkan dalam konsep seni wisata. Tujuannya adalah agar wisatawan senang, sehingga pertunjukan itu akan digemari. Prinsip konsep seni wisata yang singkat, padat, bervariasi, murah, dan telah dihilangkan unsur ritualnya, merupakan kiat tersendiri menuju satu bentuk kemasan seni wisata yang disegani wisatawan mancanegara.

Hal ini bertujuan untuk menjaga agar kesenian tradisional yang dijadikan objek sajian tetap hidup berkembang di tengah persaingan budaya global. Namun bukan berarti akan merusak kaidah-kaidah yang telah ada dalam seni tersebut, melainkan untuk memberikan alernatif sajian untuk keperluan yang lebih bebas. Hal tersebut telah ditempuh daerah tujuan wisata Bali terkait dengan upacara ritual keagamaan, namun jika memprioritaskan seni wisata tanpa melihat kepentingan yang lain yang lebih esensial, maka apa yang selama ini dikenal masyarakat berangsur angsur akan ditinggalkan penontonnya (Setia, 1987: 47)

Ungkapan tersebut menggariskan bahwa membentuk format baru seni pertunjukan wisata tidak harus merusak fungsi yang pernah ada pada seni pertunjukan itu. Oleh karenanya, konsep J. Maquet tentang pseudo traditional art dalam hal ini sangatlah tepat untuk diterapkan pada penyajian seni tradional baik yang berada di kraton (klasik) ataupun seni tradisional yang berada di pedesaan (kerakyatan). Duajenis pertunjukan yang memiliki latar belakang sejarah berbeda itu, masing masing tetap berpegang pada norma yang ada, artinya 
apa yang kita tampilkan merupakan representasi seni klasik atau kerakyatan, meskipun sifatnya hanyalah tiruan bentuk aslinya. Dengan demikian apa yang disajikan untuk atraksi wisata kepada wisatawan secara visual tetap mencerminkan ciri khas tradisi yang mereka miliki. Hanya saja secara substansi ada beberapa hal yang tidak bisa ditampilkan, salah satunya adalah unsur sesaji sebagai bagian acara ritual. Demikian pula untuk durasi penyajian, baik seni pertunjukan klasik maupun kerakyatan masing masing memiliki ciri tersendiri terkait dengan panjang pendeknya penyajian. Seni pertunjukan klasik seperti Bedaya biasa ditampilkan dua hingga tiga jam untuk acara seremonial di dalam kraton. Namun demikian untuk kepentingan wisata bisa dikemas pendek dengan durasi maksimal tiga puluh menit saja. Hal serupa juga terjadi untuk penyajian seni kerakyatan Jathilan. Secara utuh Jathilan bisa disajikan dua jam. Tentunya penyajian itu untuk acara seremonial tertentu yang mensyaratkan rangkaian Jathilan secara utuh. Namun untuk kepentingan wisata Jathilan kini bisa dikemas menjadi maksimal duapuluh menit saja. Ada perbedaan prinsip dalam penyajian Jathilan dalam durasi pendek ini dibanding dengan Jathilan yang utuh. Salah satu aspek yang dapat diungkapkan di sini adalah adegan intrance (ndadi), jika dalam Jathilan utuh memang benar benar ndadi, namun untuk kepentingan wisata ndadi yang dilakukan penari adalah tiruan dari kenyataan. Artinya ndadi dalam penyajian Jathilan durasi pendek hanyalah akting ndadi (Wawancara dengan Ki Sancoko, 3 Maret 2010).

\section{Pengaruh Globalisasi terhadap Bentuk Sajian Jathilan di DIY}

Semenjak tari klasik masuk dalam agenda wisata, kesenian kerakyatan pun mulai mengambil bagian di dalamnya. Salah satu jenis kesenian rakyat itu adalah Jathilan yang digelar di berbagai tempat wisata di Daerah Istimewa Yogyakarta. Salah satu kawasan wisata itu adalah Tlogo Putri Kaliurang yang tercatat sebagai tempat pertama pertunjukan kesenian rakyat untuk wisatawan di Kabupaten Sleman yang menggelar atraksi sejak pukul 10.00-12.00 WIB. Berbagai jenis kesenian rakyat ditampilkan di tempat ini, salah satunya adalah Jathilan yang menjadi primadona pengunjung (wisatawan). Atraksi kesenian rakyat di Tlogo Putri ini secara resmi mulai digelar tahun 1996, pada saat itu digelar festival kesenian rakyat se Kabupaten Sleman (Wawancara dengan Sancoko, 6 Juni 2010)

Awal dari pementasan di kabupaten Sleman tersebut memicu potensi kesenian rakyat di wilayah lain di Daerah Istimewa Yogyakarta untuk membuat kemasan khusus wisatawan. Secara bertahap tetapi pasti, salah satu wilayah kecamatan di Sleman yakni kecamatan Gamping, bahkan menempatkan grup Jathilan bernama Kudha Pranesa menjadi salah satu grup andalan Sleman. Keandalan grup ini dibuktikan grup tersebut dengan masuk studio rekaman yang menghasilkan cassette VCD dan audio. Setting penampilan Jathilan Kudha Pranesa untuk VCD dilakukan di halaman candi Prambanan yang merupakan objek wisata yang telah dikenal wisatawan. Dengan itu pula maka langkah promosi wisata dengan menampilkan Jathilan sebagai ikon kesenian tradisional di era industri pariwisata sudah mulai dirasakan. Realitas tersebut memacu grup grup kesenian lain untuk terus melakukan pembenahan dan peningkatan kualitas penyajian. Dari sisi ini jelas bahwa kehadiran industri pariwisata mampu memotivasi grup-grup kesenian untuk meningkatkan kualitas penampilan grupnya masing masing.

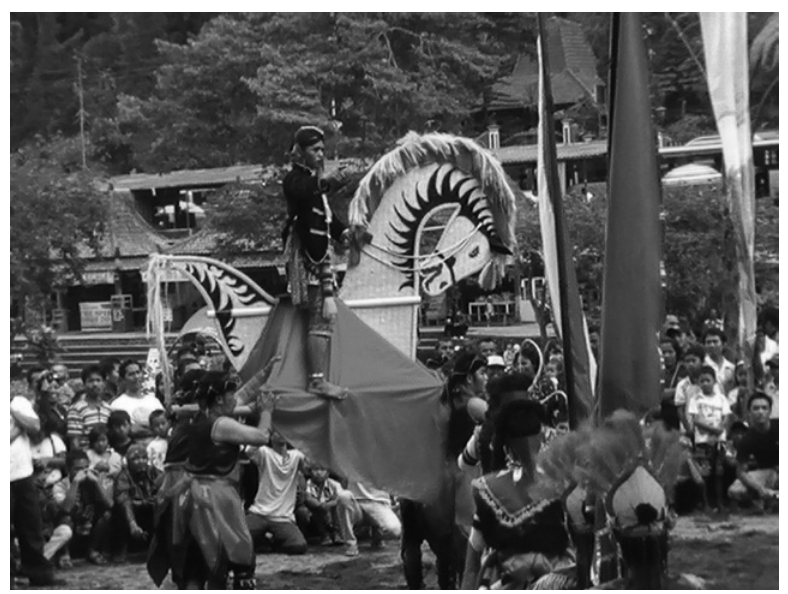

Gambar 2 :

Inovasi Jathilan dengan Kuda Kepang Raksasa (foto: Santyo, 2011)

Perkembangan berikutnya, persebaran pertunjukan Jathilan untuk wisatawan dilakukan di Kabupaten Bantul, Kulon Progo dan Gunung Kidul. Di Kabupaten Kulon Progo atraksi wisata yang menghadirkan kesenian rakyat dilakukan di objek wisata strategis seperti pantai 
Glagah, Waduk Sermo dan di Padepokan seni Bodronoyo, Kahyangan, Girimulyo. Demikian pula yang terjadi di Kabupaten Gunung Kidul, tempat wisata menjadi sasaran untuk menggelar pertunjukan rakyat, yakni Rongkop, Kukup, dan pantai Baron. Seperti dituturkan Ristu, salah satu pembina kesenian dari Dinas Pariwisata dan Kebudayaan Kabupaten Gunung Kidul, alasan utama dipilihnya tempat wisata untuk pertunjukan kesenian rakyat adalah masalah efektivitas lokasi. Karena Kabupaten Gunung Kidul wilayahnya sangat luas, sehingga pertunjukan kesenian rakyat ini sekaligus menghibur wisatawan di tempat wisata merupakan jalan terbaik yang ditempuh (Wawancara dengan Danang Murtianto, 15 Juli 2010)

Untuk kawasan Bantul pergelaran kesenian rakyat dilokalisir di kawasan GMT (Gabusan, Manding dan Tembi). Tiga wilayah ini sangat potensial untuk dikunjungi wisatawan. Selain terdapat pusat kerajinan dan cinderamata, di tempat ini juga merupakan gudangnya seniman pertunjukan (tari dan karawitan) Bantul. Semenjak diresmikannya kawasan ini oleh Bupati Bantul Idham Samawi tahun 2004, jumlah kunjungan wisatawan ke Bantul meningkat. Oleh sebab itu dibangun pula di kawasan Gabusan sebuah panggung kesenian untuk mempertunjukkan kesenian khas kabupaten Bantul yang salah satunya menampilkan kesenian Jathilan (Wawancara dengan Ki Jiwaraya, 23 Mei 2010)

Dengan aneka ragam bentuk sajian Jathilan yang ditampilkan masing-masing kabupaten dan kota di tempat wisata, ternyata memiliki ciri dan gaya yang berbeda satu sama lain. Perbedaan tersebut dari orientasi garap gerak, pola penyajian (adegan), kostum, tema cerita maupun musik iringannya. Namun demikian dari berbagai perbedaan dari sisi artistik tersebut, terdapat satu hal yang sama dalam pola pengemasannya, yakni mengacu pada konsep seni wisata yang merupakan tiruan bentuk aslinya, singkat padat, penuh variasi, dan murah harganya (Soedarsono, 1999: 5) Satu hal yang tidak bisa dihilangkan adalah menghilangkan unsur ritual. Karena pada kenyataannya wisatawan khususnya wisatawan asing lebih senang melihat Jathilan yang menyertakan acara ritual sebelum dan sesudah pertunjukan Jathilan. Hal ini seperti diungkapkan Yudono, kepala seksi adat dan nilai tradisi Dinas Pariwisata, Kebudayaan, Pemuda dan Olah Raga, Kabupaten Kulon Progo yang menyatakan bahwa mereka (wisatawan) sangat antusias melihat prosesi ritual sebelum pertunjukan Jathilan dimulai. Pada acara merti desa misalnya, prosesi ritual menjadi daya tarik sendiri di luar pertunjukan keseniannya (Soedarsono, 1999: 5)

Kehadiran pariwisata sebagai akibat arus globalisasi, mampu memberikan dampak sangat positif bagi tumbuh kembangnya kesenian itu sendiri. Hal ini dapat dilihat dari berbagai bentuk kesenian yang hidup berkembang di berbagai wilayah di Daerah Istimewa Yogyakarta tidak dapat terlepas dari kehidupan masyarakatnya yang memunculkan ciri daerah. Keunikan dan karakteristik masyarakat itulah yang mampu memberi daya tarik sebuah kesenian, tidak hanya dilihat dari aspek tontonan di atas panggung saja, melainkan di balik pertunjukan itu dapat pula dijadikan objek tontonan wisatawan. Hal ini sesuai dengan apa yang diungkapkan Schechner tentang perfomance studies, yang memberikan gambaran tentang pentingnya momentum di luar pertunjukan sebagai daya tarik lain yang pantas dicermati.

\section{Pengaruh Globalisasi terhadap Pola Sajian (Garap) Jathilan di DIY}

Pola sajian secara keseluruhan meliputi tiga babak. Pertama bagian pembuka (introduksi). Kedua disebut dengan babak inti beksa, dan ketiga penutup. Pada bagian babak penutup ini Jathilan selalu menghadirkan adegan trance atau ndadi. Seiring dengan perkembangan zaman, pola sajian Jathilan saat ini tidak selalu diikuti dengan ndadi. Hal ini dikarenakan penenerapan konsep seni wisata yang mensyaratkan pertunjukan harus singkat padat, meskipun meniru bentuk aslinya. Oleh karenanya, adegan ndadi yang disajikan kadang hanya berpura pura (acting) dari penari yang secara sadar telah diskenario oleh pimpinan grup Jathilan. 


\section{Urutan adegan baku sajian Jathilan yang dianut kelompok kelompok Jathilan di Daerah Istimewa Yogyakarta}

Kehidupan seni di berbagai wilayah di DIY, memiliki ciri yang tidak bisa dibandingkan dengan daerah lain. Keunikan ini memberikan daya tarik untuk dikunjungi tamu dari luar daerah. Munculnya industri pariwista memberikan angin segar bagi kehidupan seni tradisional yang secara alami hidup berkembang di komunitasnya. Keberadaan kesenian tradisional yang ada di desa desa memberikan peluang untuk dikunjungi wisatawan yang ingin melihat kesenian beserta aspek pendukung lain di luar pertunjukan itu. Aspek pendukung itu tidak lain adalah sisi kehidupan masyarakat di mana kesenian itu tumbuh dan berkembang. Keterkaitan kesenian dan konteks kebudayaan masyarakat ini merupakan potret kehidupan masyarakat yang secara alami dapat dinikmati oleh wisatawan dari luar, baik domestik maupun mancanegara.

Secara koreografis, Jathilan memiliki pola standar yang telah turun temurun diikuti oleh grup grup kesenian yang ada. Pola tersebut meliputi maju baris dua dua sejajar yang diawali dengan keluarnya tokoh punokawan Penthul Tembem. Pola kedua adalah pola ajeng ajengan (berhadap hadapan) antara pasukan dari sisi kiri dan sisi kanan. Pola ketiga adalah melingkar yang terdiri dari dua bagian. Pertama melingkar pola kelompok kecil, dan kedua melingkar dengan pola kelompok besar. Pada bagian akhir saat posisi melingkar merapat sebelum penari mengalami trance (ndadi). Setelah fase tersebut, pola lantai Jathilan menjadi bebas (broken) sesuai dengan keinginan penari.

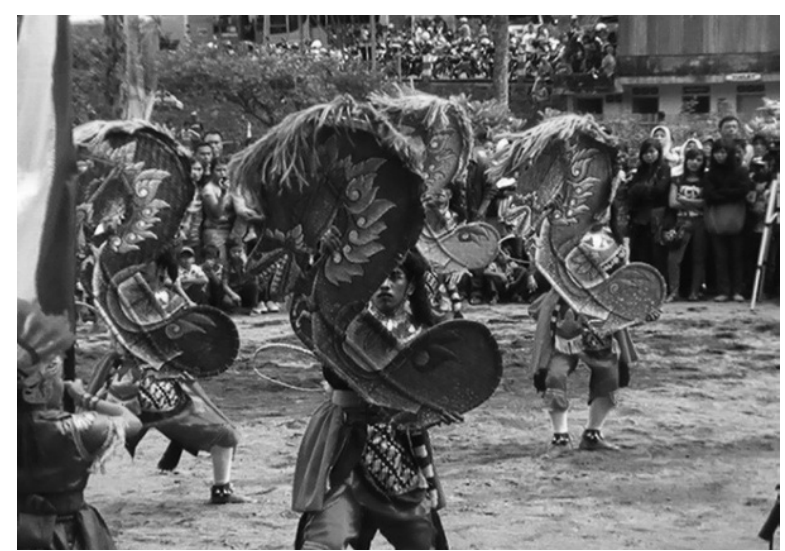

Gambar 3: Pola garap (koreografi) Jathilan kini makin varatif dan dinamis (Foto: Santyo, 2011)

\section{Pengaruh Globalisasi terhadap pola Iringan Jathilan}

Pola iringan Jathilan kini telah berubah seiring dengan tuntutan dan dinamika zaman. Pada awalnya iringan Jathilan masih sangat sederhana dengan instrumen terdiri atas: kendhang, angklung, bendhe dan kecer, seperti terlihat dalam gambar berikut ini.

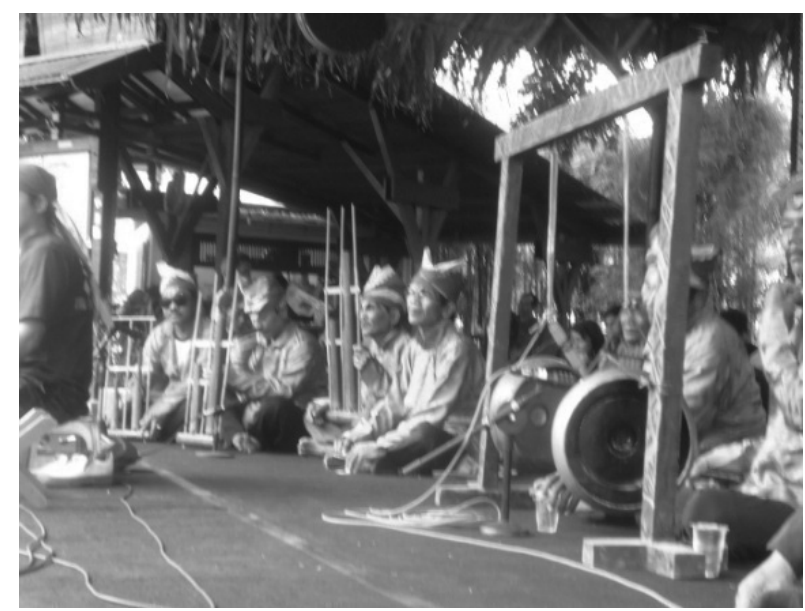

Gambar 4: Instrumen Jathilan baku terdiri atas; bendhe, angklung, kecer dan kendhang (Foto: Santyo, 2011)

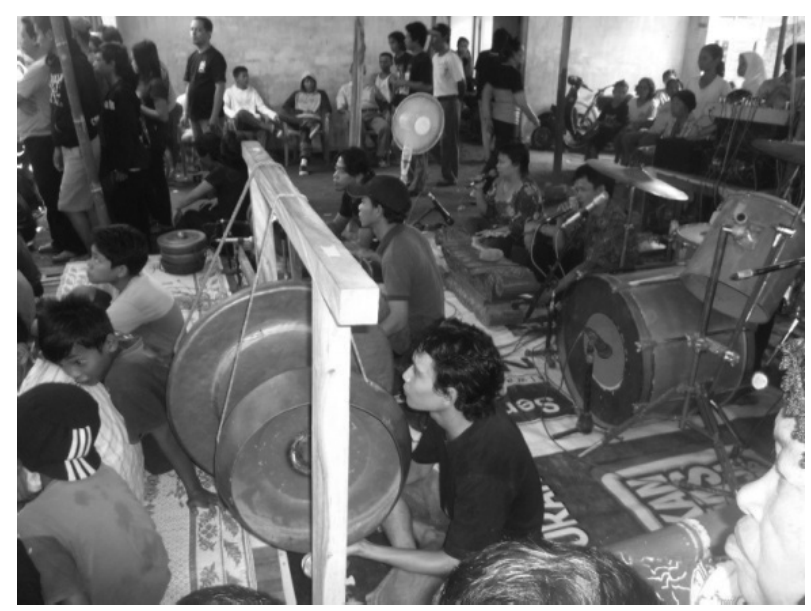

Gambar 5: Instrumen Jathilan yang sudah berkembang dengan drum dan keyboard (Foto: Santyo, 2010)

Di samping itu terdapat pula iringan khas Jathilan Incling dari Kulon Progo yang menggunakan Krumpyung sebagai pengiringnya. Krumpyung adalah instrumen gamelan terbuat dari bambu. Kesenian Krumpyung itu sendiri saat ini masih hidup berkembang di wilayah bagian barat Kulon Progo berbatasan dengan Kabupaten Purworejo. 


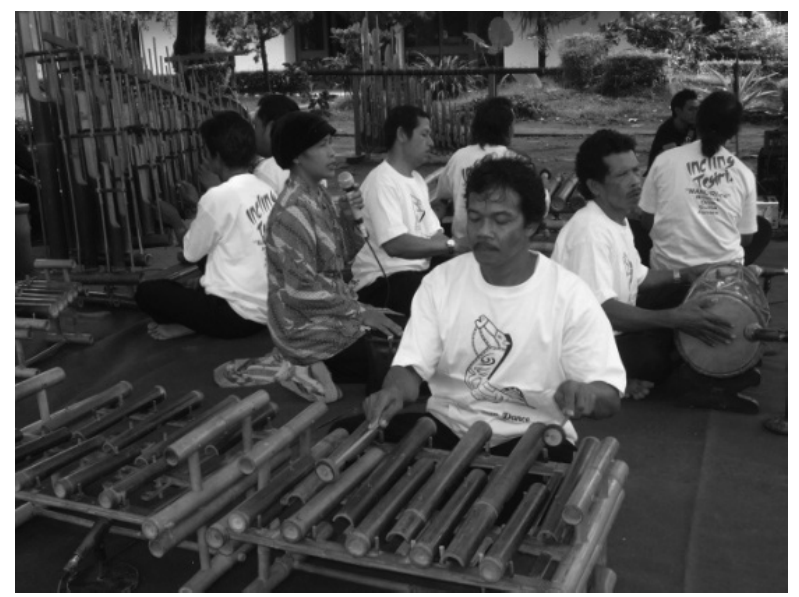

Gambar 6: Instrumen Krumpyung untuk iringan Jathilan Incling Kulon Progo (Foto: Santyo, 2010)

Perkembangan saat ini iringan Jathilan semakin variatif dengan masuknya musik campursari sebagai bagian dari iringan Jathilan. Hadirnya drum dan keyboard serta simbal dalam mengiringi Jathilan menambah daya tarik khususnya untuk generasi muda. Hal ini terlihat dari event festival Jathilan se Daerah Istimewa Yogyakarta medio Juni 2011 lalu di kawasan wisata Tlogo Putri Kaliurang. Mayoritas sajian Jathilan menggunakan pola iringan kreasi baru yang menyisipkan drum dan atau keyboard sebagai bagian dari iringannya. Bahkan untuk acara tertentu di kawasan wisata Glagah, Jathilan diiringi dengan musik ndangdut, meski tidak meninggalkan pola baku bendhe dengan tabuhan ritmis sebagai penuntun irama Jathilan yang khas. Dalam sajian Jathilan ndangdut, ketika adegan trance, penari yang kerasukan bisa meminta lagu kepada pengiring yang diinginkan. Lagu favorit penari yang sedang ndadi adalah Cucak Rawa dan Nyidham Sari.

Desain atau rancangan kostum yang berkembang saat ini adalah dengan pola tradisi lama yang telah dimodifikasi dalam bentuk kreasi. Salah satu contoh yang dapat diungkapkan di sini adalah irah-irahan atau penutup kepala yang berpola pada model tekes pada cerita panji. Kini telah dimodifikasi menjadi model rambut punk rock ala musisi barat yang pernah menjadi idola di era 1980-an.

\section{Penutup}

Kajian mengenai pengaruh Globalisasi terhadap perkembangan kesenian Jathilan yang terjadi di Daerah Istimewa Yogyakarta ini sangat kompleks. Apa yang diungkap dari hasil penuturan tokoh Jathilan di DIY menyebutkan adanya kecenderungan masyarakat jenuh dengan pola pola lama (baca: tradisi) yang membuat kesenian Jathilan stagnan. Seiring dengan perubahan dan perkembangan zaman, maka mereka melakukan gebrakan untuk membuat dan mengemas kembali bentuk bentuk sajian Jathilan yang relevan dengan situasi zamannya. Munculnya Jathilan Gaul karya Satriyo Handito, Jathilan Penangsang karya Yata, adalah bukti bahwa kreativitas yang melingkupi kesenian tradisional Jathilan selalu muncul seiring dengan bergulirnya waktu.

Pengaruh dunia Globalisasi tidak dapat dihindari. Dan ini adalah sebuah tantangan yang harus dihadapi. Dari berbagai sendi kehidupan, masyarakat telah ikut dalam arus Globalisasi. Demikian pula dengan seni pertunjukan kerakyatan Jathilan. Segala aspek itu akhirnya mampu menyatu bagaikan simbiose mutualisme dalam sebuah sajian yang akhirnya juga diminati masyarakat pada habitatnya. Dengan itu pula kesenian Jathilan kini menjadi lebih variatif, dinamis dan secara kuantitas berkembang serta diminati generasi muda.

\section{Kepustakaan}

Daniel L. Pals. 1996. Seven Theories of Religion, alih bahasa oleh Ali Noer Zaman, Yogyakarta: Qalam.

Grabburn. Nelson, H.H. 1976. Ethnic and Tourist Arts, Berkeley: University of California Press, 1976), 71. Nelson H.H. Grabburn, 1976, Ethnic and Tourist Arts, Berkeley: University of California Press.

Kayam, Umar. 1981. Seni, Tradisi, Masyarakat, Jakarta: Pustaka Pelajar. , 1980. Sejarah Antropologi I, Jakarta: UI Press. 
Nuryani, Wenti. 2008. "Nilai Edukatif dan Kultural Kesenian Jathilan di Desa Tutup Ngisor, Magelang Jawa Tengah", Tesis S2 - Pasca Sarjana UNY.

Setia, Putu. 1987. Menggugat Bali, Jakarta: PT. Temprit.

Soedarsono, R.M. 1999. Seni Pertunjukan Indonesia dan Pariwisata, Bandung: MSPI.

Soedarsono, R.M. 2002. Seni Pertunjukan Indonesia di Era Globalisasi, Yogyakarta: Gadjah Mada Press.

\section{Informan}

Wawancara dengan Sancoko, wakil ketua Paguyuban Jathilan DIY, di Godean Sleman, tanggal 2 Maret 2010.

Wawancaka dengan Ki Jiwaraya, tokoh seni kerakyatan Bantul, , tanggal 23 Mei 2010.

Wawancaka dengan Danang Mutiyanto, pembina kesenian Jathilan Kabupaten Gunung Kidul, tanggal 15 Juli 2010. 